\title{
Metacognitive Knowledge and Mathematical Intelligence-Two Significant Factors Influencing School Performance
}

\author{
Vlastimil Chytrý ${ }^{1, *}$, Jaroslav Říčan ${ }^{2}$, Petr Eisenmann ${ }^{3}$ and Janka Medová ${ }^{4, *}$ (D) \\ 1 Department of Preschool and Primary Education, Faculty of Education, Jan Evangelista Purkyne University, \\ 40096 Ústí nad Labem, Czech Republic \\ 2 Department of Pedagogy, Faculty of Education, Jan Evangelista Purkyne University, 40096 Ústí nad Labem, \\ Czech Republic; jaroslav.rican@ujep.cz \\ 3 Department of Mathematics, Faculty of Science, Jan Evangelista Purkyne University, 40096 Ústí nad Labem, \\ Czech Republic; petr.eisenmann@ujep.cz \\ 4 Department of Mathematics, Faculty of Natural Sciences, Constantine the Philosopher University, \\ 94974 Nitra, Slovakia \\ * Correspondence: vlastimil.chytry@ujep.cz (V.C.); jmedova@ukf.sk (J.M.)
}

Received: 11 May 2020; Accepted: 8 June 2020; Published: 12 June 2020

\begin{abstract}
Metacognitive knowledge and mathematical intelligence were tested in a group of 280 pupils of grade 7 age 12-13 years in the Czech Republic. Metacognitive knowledge was tested by the tool MAESTRA5-6+. Mathematical intelligence is understood as an important criterion of a learner's ability to solve mathematical problems and defined as the specific sensitivity to the six particular phenomena: causality, patterns, existence and uniqueness of solution, geometric imagination, functional thinking, and perception of infinity. The main objective of the research is to explore relationships and links between metacognitive knowledge and mathematical intelligence of the learners and discover the scope of impacts of their metacognitive knowledge on the school success rate. Based on the collected answers and nearly zero correlation $(r=0.016)$ between the researched domains, a two-dimensional model considering the correlations between metacognitive knowledge and mathematical intelligence was designed. The developed model enables to describe an impact of the domains on the learner's school performance within the selected school subjects, and concurrently, it emphasizes their importance within the educational practice as such.
\end{abstract}

Keywords: mathematical intelligence; mathematics education; metacognitive knowledge

\section{Introduction}

In order to fulfill and satisfy the needs of the 21 st century society based on the actual knowledge and information for the informed citizens to be able to think critically, the problem-solving should become an integral part of current mathematics education practice. Mathematical intelligence [1-3] and metacognitive knowledge [4-10] are considered as important predictors of the ability to solve mathematical problems. Moreover, there is general agreement among researchers involved in the field of mathematics education that the main constitutes of metacognitive knowledge, i.e., knowledge of cognition, and control and regulation of cognition [11,12] fit with the demands of fast-changing world of the contemporary society $[13,14]$ for the ability to learn independently and adapt to new learning tasks [15]. Evidently, critical thinking is strongly influenced by factors such as conceptual understanding, procedural fluency, and metacognitive knowledge [16]. Perry et al. [17] provided strong evidence that effective teaching of metacognition would result in better achievements and outcomes of pupils. On the other hand, there is only little research done in the field of relations between 
metacognition and pupils' wellbeing, however a few existing studies report some very positive impacts of metacognitive knowledge as such.

Even though the relation between metacognition and ability to solve mathematical problems is well-documented [18-21] by now, we are not aware of any research evaluating the dependency between metacognitive knowledge and the preconditions for solving mathematical problems, i.e., sensitivity to the basic aspects such causality, patterns, existence and uniqueness of solution, geometric imagination, functional thinking, and perception of infinity covered in general by the term mathematical intelligence. In this study we would like to shed more light on the interesting link between metacognitive knowledge and the preconditions for solving mathematical problems from the psychological point of view, considering the fluid intelligence as well.

There is a wide consensus among the researchers that the common problem solving skills can form an inherent basis for successful mathematics education [22]. Definitely and clearly, the processes activated in the individual phases include metacognitive processes. Numerous curricular documents advantageously [23] consider grasping of problem-solving skills as an integral part of mathematical education and not as the particular topic to be learned there. The Czech national curriculum states that "these problems should underlie the all thematic areas in whole primary and lower secondary education" [24], similarly to the National Council of Teachers of Mathematics (NCTM) stating that problem solving is an integral part of the whole and all mathematics learning, and so it should not be an isolated and separate part of the mathematics program [25]. We anticipate that to include problem solving into the numerous diverse and different fields of mathematics can improve the ability of pupils to think critically [26] and their productive disposition as well, i.e., ability to use their mathematics knowledge outside the classroom moreover. This can lead to the positive development in the field of productive disposition, acquiring an ability to see the factual and functioning value of mathematics out of the school environment, almost everywhere, and easily in addition. The National Research Council defines the mathematical proficiency [27] as an actual inclusion of the following five interdependent strands: (1) conceptual understanding; (2) procedural fluency; (3) strategic competence; (4) adaptive reasoning; and (5) productive disposition. Whereas, the strategic competence is defined as "the ability to formulate mathematical problem, represent them; and solve them" (p. 124), we consider it as strongly connected and interrelated with metacognitive monitoring [28] as well.

The all and whole problem-solving processes are closely connected to the concept of metacognition; and therefore the correlation between the learner's performance in mathematics and single components of metacognition have been proven evidently in the past four decades [8,29-31]. As soon as in the 1980s, the researchers in the field of problem solving agreed that the poor performance of pupils in problem solving in mathematics was not only caused by a lack of an adequate knowledge but rather by the pupil's inability to organize, grasp, implement, and monitor what the pupil already knew (including evaluating the adequacy of available resources), and fully understand the assignment of a task [32-34]. In other words, pupils often have enough of the necessary, factual, and procedural knowledge that is needed to solve common non-routine tasks. However, they are not able to regulate and grasp their resources reasonably and effectively in the end. This study focuses on the ontologically older and a more stable field of metacognition working as a precondition or requisite for metacognitive processes, e.g., planning, monitoring, evaluation [35].

\subsection{Metacognitive Knowledge}

Metacognition as such can be understood as the specific potential and capability to operate one's own thinking as an object; this includes the following two basic components: (i) The stable part ("off-line") covering metacognitive knowledge; (ii) metacognitive regulation referring to the processes of activities ("on-line") involving necessary capabilities and active aspects such as prediction, planning, monitoring, and evaluation of the conducted cognitive activities [36]. Even though the metacognitive development cannot be considered from the linear view solely, on the other hand, metacognitive knowledge as such is gradually and conceptually built up earlier than the required 
metacognitive regulation [37] as such. Hence, metacognitive knowledge refers to the actual individuals' extent of knowledge of their cognitive strengths and weaknesses. The relevant field includes the given learner's knowledge of outer and inner factors that might influence and enhance any cognitive processes, and the knowledge of relatively efficient use of accessible strategies and methods. In this way, their own convictions can be included, whether true or not, among this information. Therefore currently, metacognitive knowledge is usually divided into some other topics such as: (a) Declarative knowledge relating to self-cognition, abilities, skills, and characteristics of one's own learning process; (b) procedural knowledge, i.e., being responsible for conducting various learning strategies or methods and is applied in directing learners during the problem-solving process and learning activities; (c) conditional knowledge containing and covering awareness of when (under what conditions) and why a strategy or method should be used there [28,38,39]. Interestingly, Borkowski, Milestead, and Hale [40] add the following two aspects or topics such as: (d) metacognitive knowledge of relations being usually included into declarative knowledge or conditional knowledge. This level also covers awareness of when a strategy or method is more appropriate to a specific task compared to the other ones.

The actual problems relating to the measuring of the level of metacognitive knowledge lay mostly in the core of metacognition, i.e., it cannot be directly observed as such [41]. The monitoring process is based on detecting the amount of indicating elements that can be defined as such or those related to the metacognitive processes according to the recent theoretical background. Within the context of this study, relevant ways of detecting the structure of metacognitive development are those defined earlier by Wirth and Leutner [42]. Other authors apply some qualitative or quantitative standards-the former one considers the individual's ability to determine what strategy or method is appropriate on the background of a specific task situation; on the other hand the latter one is defined as a way of emphasizing the realistic extent and frequency in the use of strategies and methods to detect maximum rating there. Additionally, on the other hand, the qualitative standard prevails here, and thus often, any data gained by an approach based on the quantitative standards is more accurate and valid. These, as well as other authors $[43,44]$ often do point out on a stronger connection of the qualitative approach to the performance compared to quantitative standards. However, the all acquired current conclusions of researches applying questionnaires and interviews often fail in predicting learning performance as such in the end. In this study, the tool MAESTRA 5-6+ was used that was originally designed for learners from the 5 th to the half of 7 th grade focusing on the following four specific purposes: (1) What strategy or method the learner have used (declarative knowledge-knowledge of strategies), (2) in relation to other accessible ones (relation knowledge), (3) when or under what conditions (conditional knowledge) it is applied by the learner to understanding the characteristics of described, as well as (4) task situation (declarative knowledge-knowledge of the task). Deficits in any of the above mentioned fields of metacognition can result in an incorrect strategic solution in the end.

Research studies identifying metacognitive aspects in mathematics usually focus mainly on the effects of metacognitive regulation, including aspects such planning, monitoring, evaluation, and calibration on the actual problem-solving effectiveness. However, from a developmental view, it is just the declarative knowledge that appears to be a precious prerequisite for the procedural knowledge and then for the metacognitive regulation [35] as such. Therefore, Thillman et al. [45] emphasize that just the declarative knowledge and the metacognitive regulation are the two distinct components and therefore definitely emphasize their differentiation when measuring them. Hence, the declarative knowledge is particularly important in using emerging mathematical strategies as opposed to the older already known strategies [46]. A direct link between the declarative knowledge and the relevant mathematical skills has already been demonstrated among primary school pupils in the daily school practice. Implicitly and surprisingly, the pupils who could explain why and when to use arithmetic strategies and methods were also more successful in solving numerical problems [10]. Thus, such effect is also evident among upper secondary school pupils [47]. Lester and Garofalo [48] discovered an advanced declarative knowledge about metacognitive strategies among the third and fifth grade 
pupils. Here the pupils were capable to present several strategies and methods of calculation but, while on the other hand, interestingly, they did not use any elements of problem analysis, monitoring their own progress or evaluating their own results when solving problems. Among the older pupils both forms of metacognition already appear there (metacognitive knowledge as such, metacognitive regulation as well) and these are related to each other. Perrenet and Wolters [49] found a correlation between the declarative knowledge and frequent control of their own progress and corrections of their own calculations when solving linear equations among the eighth grade pupils.

\subsection{Mathematical Intelligence}

Intelligence is one of the significant components falling under the Culture of Problem Solving structure that was introduced by one of the authors of this paper as a tool for describing individual pupil's ability to solve mathematical problems [2]. According to Wenke, Frensch, and Funke [50], since the very first attempts to define the concept of "intelligence," the ability to solve problems was included in almost every definition. In addition, intelligence as such has often been viewed as one of the best predictors of the problem-solving ability and features. The history of measuring intelligence aspects can be dated back to the late 19th century and, similarly to its definition, it had been thoroughly and radically changed over the time by today. It is connected with the studies by authors as Francis Galton, Alfred Binet, Lewis Terman, Theodore Simon, Raymond Cattell, Henry Goddard etc. In the past decades, different models of intelligence were progressively published, e.g., Spearman's two-factor theory of intelligence, Guilford's three-dimensional structure of intellect, Gardner's theory of multiple intelligence, Eysenck's theory of intelligence. Thus and consequently, there were several different tests of intelligence, to name the most notable examples: the Snijders-Oomen nonverbal test, the Amthauer test, the Wechsler tests, tests Army alpha and Army beta, the Raven's progressive matrices test, the Stanford-Binet test [51]. Evidently, it appears that the recent component of intelligence should be replaced by a newer concept vested in a new indicator named as mathematical intelligence [52,53].

Juter and Sriraman [54] identified several different features for defining mathematical intelligence. In studies in the domain of cognition, mathematical intelligence in an individual can be defined as: (1) An ability to recognize, abstract, and generalize mathematical structures; (2) data handling; (3) an ability to think logically and to infer; (4) analogical, heuristic thinking, and posing related problems; (5) flexibility and reversibility of mathematical operations; (6) an intuitive awareness of mathematical proof; (7) an ability to discover mathematical principles independently; (8) decision-making abilities in problem solving situations; (9) an ability to visualize problems and/or relations; and (10) capacity to distinguish between empirical and theoretical principles. These abovementioned aspects can be covered by the following two terms such as: (1) causality, including inductive, and deductive reasoning, and (2) existence and uniqueness of solution. It is worth to mention that talented pupils, as a rule, manifesting high levels of logical-mathematical intelligence are often "fascinated with unique patterns in numbers or with science as such and will pursue ideas far beyond their apparent utility" [55]. These pupils are also able to internalize ample intricacies of logic and mathematical reasoning [56], particularly, in the field of geometry and algebra, thus they feature sole geometrical imagination and well-developed ability to recognize the patterns as such [57], whether in the field of algebra or geometry, so, it seems to be the promising factor influencing the pupils' ability to solve mathematical problems. Our previous findings [51] indicate that functional thinking and perception of infinity are just the two aspects particularly involved in the successful solution of mathematical problems. Mathematical intelligence is defined here as a specific sensitivity to the following six specific phenomena: causality, patterns, existence and uniqueness of solution, geometric imagination, functional thinking, and perception of infinity (Figure 1). 


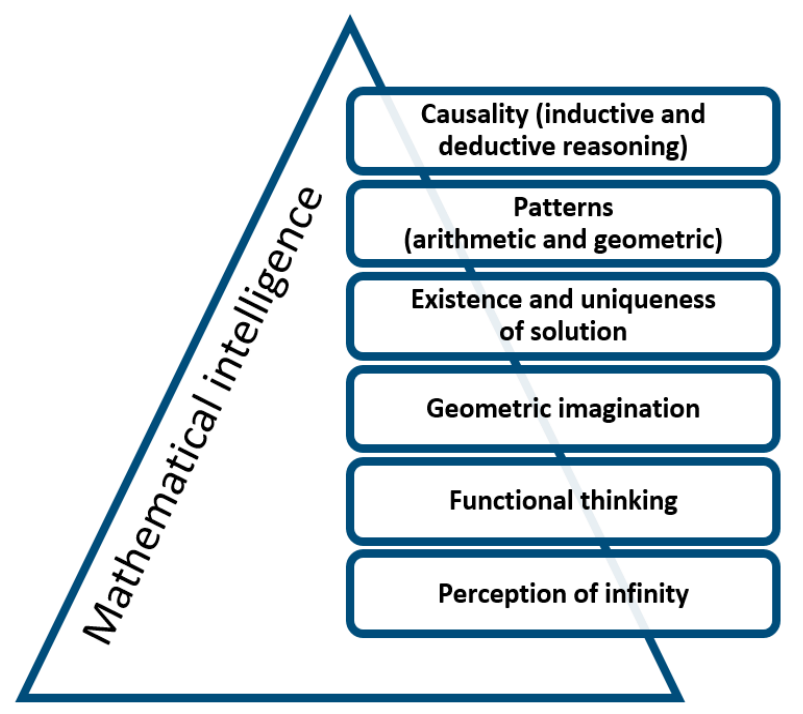

Figure 1. Mathematical intelligence and its elemental components.

\subsection{The Connection between Intelligence and Metacognition}

The question of defining relationships between the metacognition and intellectual abilities (defined as the quality and extent of the repertoire of general cognitive operations and skills available to an individual in a particular time) is not yet clearly answered [58]. Some authors have referred to the metacognition construct as "reflecting intelligence" that is defined as an ability to make mental processes and object of observation [59]. Piaget [60] talked about "reflexive abstraction" as a mechanism for extracting information, reorganizing it, and consolidating it into memory.

Currently, there are the three specific models defining basic relationships between metacognition and intelligence: (1) Metacognitive skills can be interpreted as a manifestation of intellectual abilities. Metacognition is thus defined as a part of cognitive contents; (2) metacognitive skills and intellectual abilities are thus independent concepts; (3) intellectual abilities are influential at the beginning of the development of metacognitive skills [61]. However, after this "start" they no longer affect or influence the direction of the skills development. Hence simply said, metacognition as such, in this view, can control performance functions based on the cognitive content. Some studies indicate that the third model appears to be the most probable and metacognition is largely an intelligence independent construct [62].

\section{Methodology}

\subsection{Aims}

The main aim of this study is to investigate the relation between pupils' metacognitive knowledge and mathematical intelligence and how these two factors can influence the academic performance as such within some science subjects. Since there are many factors that may affect this relationship, including the age of pupils, the study focuses solely on the pupils at the edge between the Piaget's concrete operational stage and the formal operational stage, it means on children at the age of $12[63,64]$. Some authors [65-68] also considered this age as the period when their metacognitive knowledge is in its "full blossoming." Furthermore, there is a strong evidence $[69,70]$ that the reasoning ability is only marginal for younger pupils. Therefore, the following research questions were formulated there since the beginning:

(1) What is the connection between the grade 7 pupils' metacognitive knowledge and mathematical intelligence?

(2) How can metacognitive knowledge and mathematical intelligence influence the grade 7 pupils' school performance? 
Based on the above stated, the answer to the research questions can be predicted by formulating the two research hypotheses:

Hypothesis 1. There is no direct or indirect connection between the 7th grade learner's metacognitive knowledge and mathematical intelligence.

Hypothesis 2. The combination of metacognitive knowledge and mathematical intelligence factors evidently do influence the learner's performance.

\subsection{Research Sample}

The study is based on a questionnaire survey where 280 pupils (131 girls and 149 boys) of the 7 th grade at lower secondary schools (aged 12-13) participated. All the lower-secondary schools in the region of Ústí nad Labem were asked for cooperation if the following three conditions were satisfied: (i) None of the classes were specialized in any subjects (foreign languages, mathematics etc.); (ii) all the participating schools were public to ensure that there is not any specialized approach as it is usual in case of private schools; (iii) they were traditional Czech schools. It means that alternative schools as are Montessori, Dalton and Hejnýs mathematics curricula [71] were excluded to avoid the data bias. Among these schools, there were randomly selected those where the data were collected. Before the actual data collection, a team of researchers was assembled. This team was acquainted in detail with the used method of data collection and then equipped with the unique methodology tools to evaluating acquired data. Following data were collected by the researchers under the same conditions and at the same time (the entire data were collected within 14 days). In the course of the data collection phase, respondents were always instructed when to start the test, how much time they have, when they can continue with the next part of the test, etc. In this way, any teachers' interventions were nicely minimized and objectivity in data collection was maximized.

Twenty-five learners were excluded from the testing phase for the following reasons: (i) They did not fill in any of the items, (ii) they did not understand any of the items (two Vietnamese learners), (iii) they were sick or they followed an individual learning plan (due various reasons) (some of them reached the normal distribution score; most of them had a mean score). None of the classes specialized in any subjects (foreign languages, mathematics etc.). All the pupils were of Czech nationality (with the exception of two Vietnamese pupils). All the pupils were native speakers of Czech language. The written informed consents for research from the parents of all the participating pupils were collected by the teachers.

\subsection{Tool for Researching Metacognitive Knowledge}

The tool MAESTRA 5-6+ [72] (for the German educational environment [73] and for the Czech educational environment [74]) applied in this study is a result of simplification and modification of already existing tests, e.g., WLST (Würzburger Lesestrategie-Wissentest) [43], or single tasks of PISA tests (Programme for International Student Assessment) [44]. It is specifically designed for learners from the 5th to the first half of 7 th grades. The above mentioned tools are based on the theory of specific domain character of cognitive processes, i.e., there does not exist one joint set of all these processes but human mind is structured into such models that are mutually more or less independent and each of them is responsible for and able to process a specific type of input. The Czech localization of the tool was validated in our previous study [74] and the value of Cronbach $\alpha$ calculated for given dataset was 0.86 which can be considered as the sufficient reliability level.

The core of this tool is to process relevant diagnostics of the learner's ability to distinguish under what conditions the proposed strategy is appropriate in the context of the given learning scenario [42]. The tool making processing is based on the use of the five specific mathematical scenarios (an example of the scenario and learning strategy is shown in Figure 1). Various strategies offered within individual scenarios (strategies A-F in Table 1) correspond to the four-stage cognitive activity model involved in 
the process of mathematical problem-solving that includes [75] the following phases: (1) understanding the task assignment (understanding the problem and its definition); (2) planning separate solution steps (designing solution strategies); (3) implementation of the plan (implementation of strategies); (4) evaluation and reflection of the solution (looking back to verify the conclusions, checking the results).

Table 1. A sample of specific scenario of the MAESTRA 5-6+ tool.

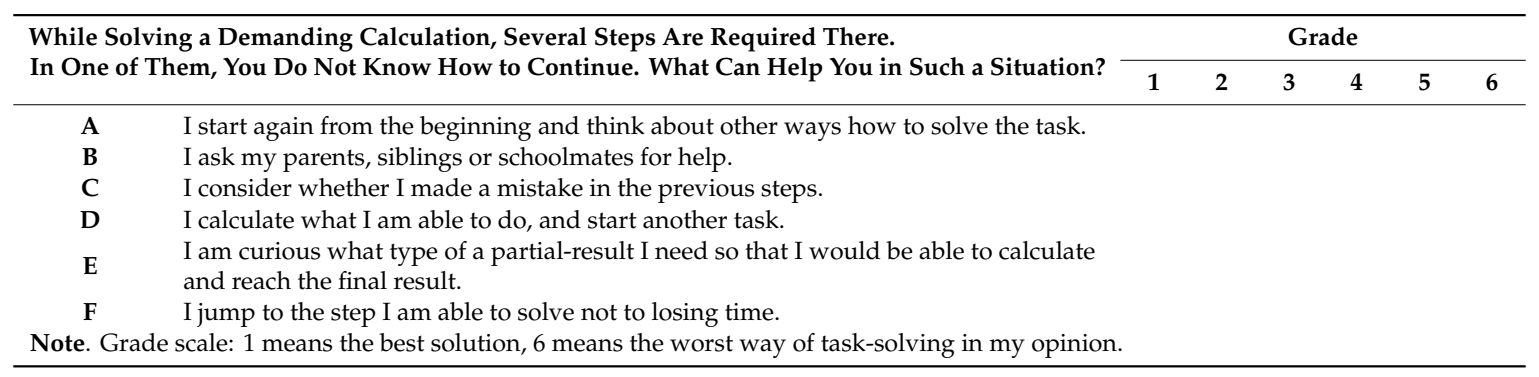

For each of the offered strategies, pupils assign their ratings from 1 to 6 (where 1 means the best and 6 means the worst). Here, the pupils can assign the same assessment to some two different strategies (e.g., 4, 4). The evaluation is carried out in pairs (as each strategic alternative is compared to the other offered strategic alternatives) and it does not matter by how much one strategy is rated higher than the other. For instance, if a pupil prefers the strategy A over the strategy B, it is irrelevant whether the difference in reference values is 1,2, or 5. Importantly, one of the strategies (A in this case) is prioritized over another one ( $\mathrm{B}$ in this case). The values obtained from the pupils are compared with a data matrix obtained from experts [76]. An expert in this research is considered to be a person who has obtained a PhD degree in didactics of mathematics.

If the pupil's assessment coincides with the expert opinion, then the pair comparison is considered correct (the pupil is assigned by value 1). However, if it is not in accordance with the expert opinion, it is assessed as incorrect (the pupil is assigned by value 0 ). Whereas more experts collaborated in the validation of the tool, and the outcome of the expert's judgment is largely dependent on accuracy of the description covering the validated element, its components and quality of the experts involved there it was necessary to determine how much consensus in their judgment is required there. The criterion limit was set at $80 \%$, i.e., at least 4 out of 5 experts had to agree that, for instance, in Table 1 , the strategic alternative A is more appropriate than the strategic alternative B $(a>b)$. In total, 65 pairwise comparisons were obtained from the experts for the five scenarios. In the three of them, experts were choosing from the six strategies and in the two of them from the five strategies. This number was obtained on the basis of the basic combination calculus that proceeds from the formula $3 V_{2}(6)+2 V_{2}(5)=65$. The aforementioned criterion limit and selectivity resulted in an expected reduction in the number of pairwise comparisons. A total of 34 pair comparisons was generated (not 65 but only 34 due to the required $80 \%$ agreement among experts, while 31 cases were less consistent) from the 28 strategies $(6+6+5+5+6)$ presented to the pupils in the five task situations. The time limit for administering the test was 20-25 min. A sample item of the tool is presented in Table 1.

\subsection{Tool for Investigating Mathematical Intelligence}

The test of mathematical intelligence consisted of the 12 specific problems. Always two problems correspond to one particular phenomenon of the definition of mathematical intelligence, specifically covering such aspects as: causality, patterns, existence and uniqueness of solution, geometric imagination, functional thinking, and perception of infinity. The items in the test were collected from several sources, using the Vanderberg and Kuse Mental Rotation Test [77], the Guilford test of Divergent Thinking, and in addition using a figural item of the Torrance Creativity Test [78]. However, all these selected tests are based on the Eysenck Intelligence Test [79]. 
Nine of the test items were closed multiple-choice tasks with only one correct answer, two items were the short answer items with unique solution, and one item has more correct solutions. Five of the items were divided into smaller parts. Each item was assessed on the scale $0-5$ based on strictly defined criteria and the total sum indicated the index of mathematical intelligence. Initially, each of the three coders were trained by coding ten of the pupils' solutions and confronting their coding with the authors of the test. The three of the test items are presented (Figures 2-4). The test lasted $15 \mathrm{~min}$. All the tested pupils worked independently, they were allowed to use only simple calculators. All the problems of the test were evaluated by the authors of this paper. The test was validated in the Czech educational environment [53]. Here, the reliability level of the entire test is $\alpha=0.57$ which allows to consider the reliability as sufficient.

Task 1. Select one of the pictures 1-3 which, after being turned, is identical with the original one. Circle the number of your answer.

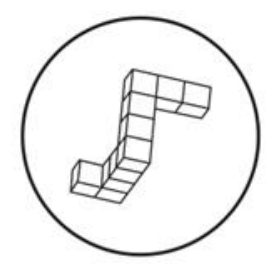

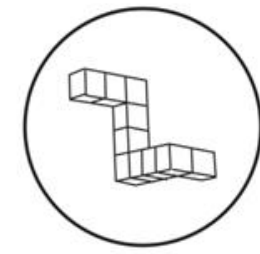

1

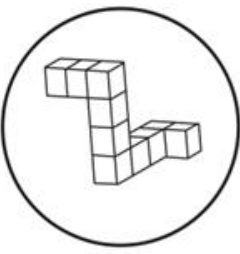

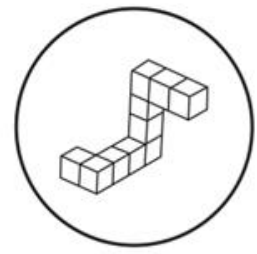

3

Figure 2. Assignment of the Task 1 .

Task 2. This pattern was made of matches.

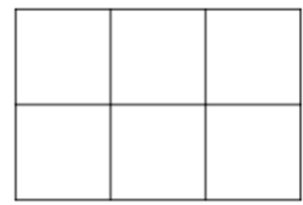

Remove any matches to receive three squares. Draw your solutions in the figures below; cross the removed matches. Find as many solutions as possible.
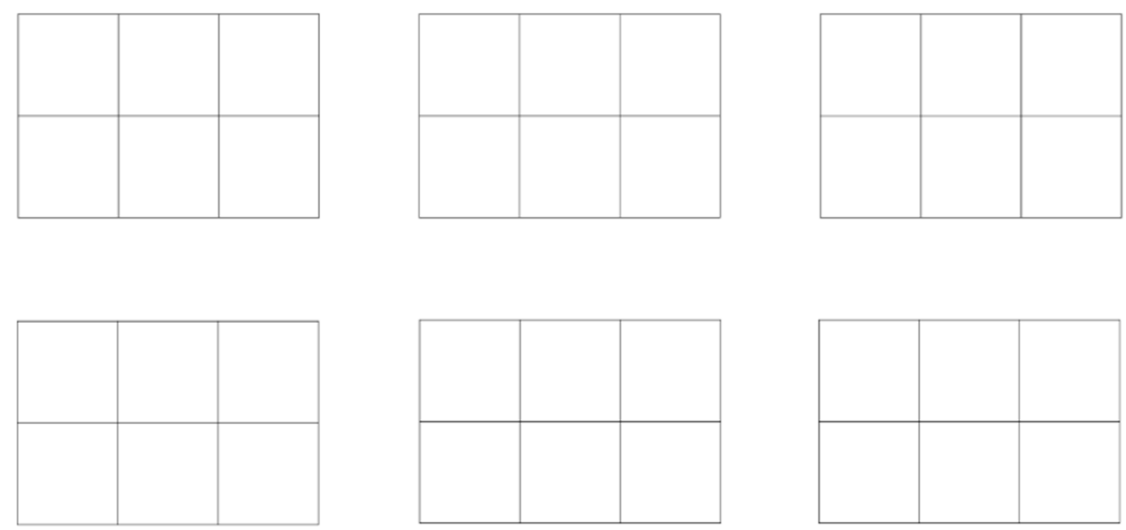

Figure 3. Assignment of the Task 2. 
Task 3. Add a sign ",,$+- \times, \div$ " between the figures to solve the equation. Do not change the order of figures.

$$
\begin{array}{lllll}
9 & 6 & 8 & 7 & 6
\end{array}
$$

Figure 4. Assignment of the Task 3.

\subsection{Statistical Analysis}

In order to determine reliability of the test scales and subscales, standard methods used in pedagogical research were utilized. The value of Cronbach $\alpha[80,81]$ was calculated. According to Shoukri and Cihon [82], the reliability coefficient $r$ is considered excellent if $r$ is higher than 0.75; good if $r$ is between 0.40 and 0.75 ; and poor if $r$ is less than 0.40 . This is an acceptable value because only the six items were used there. To assess actual dependence or an independence of individual quantities, Spearman's correlation coefficient was used. The level of significance $\alpha=0.05$ was used in all tests. Calculations were carried out in the programme STATISTICA 12.0 (StatSoft Inc., TIBCO Software, Palo Alto, CA, USA). The Shapiro-Wilk test [83] was used to assess normality of data distribution (metacognitive knowledge $W=0.971, p<0.001$, mathematical intelligence $(W=0.954, p<0.001)$. Reflecting these results, therefore non-parametric statistic methods were applied. To compare more than two groups the Kruskal-Wallis ANOVA [84] was used, followed by the post hoc analysis (multiple comparison) conducted by the Dunn method [85], in case of balanced distribution the Neményi method was applied in the end.

\section{Results}

The presented research is based mainly on the correlation analysis to determine tightness of the relationship between variables. As null hypothesis $H_{0}$ was rejected in testing normality in both metacognitive knowledge and mathematical intelligence, the Spearman correlation coefficient is used for testing the null hypothesis stating that $r=0(r=0.016, t(N-2)=0.269, p=0.788)$. In this case, $r^{2}=0.0003$ expresses the impossibility of explaining the rate of variability of one variable on the other, what results in the fact the null hypothesis cannot be rejected and the alternative hypothesis is verified. Based on the correlation values by Chráska [86], there is an absolute independence between the items, thus, they do not correlate, as displayed in regular and frequency scatterplots (Figure 5) demonstrating independence of both variables.
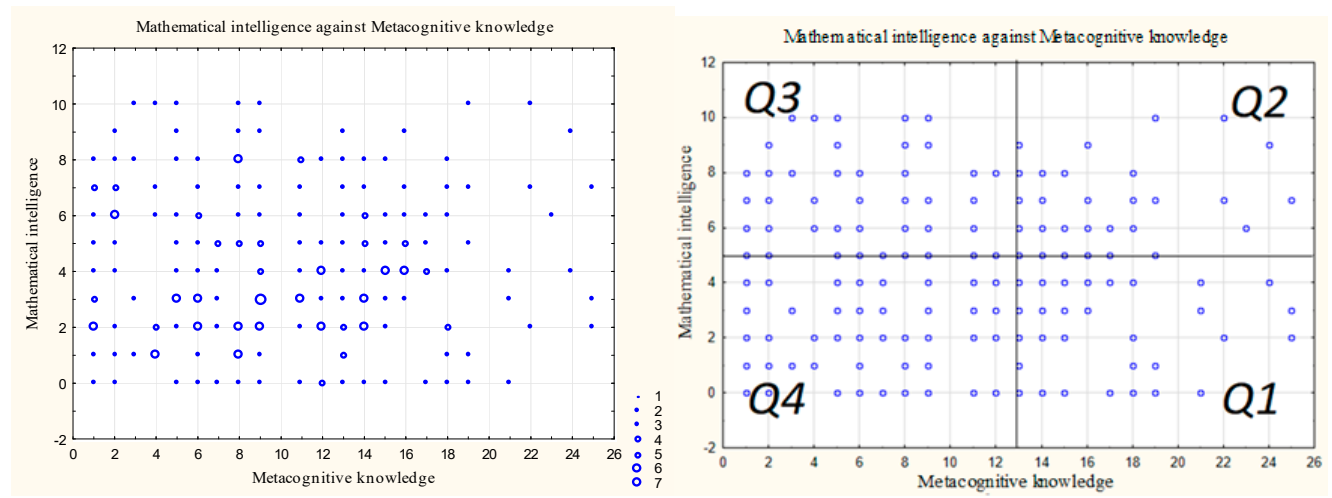

Figure 5. Regular and frequency scatterplots of metacognitive knowledge and mathematical intelligence.

Reflecting the independence of both variables, respondents can be divided into the four quadrants, following the set of inequalities (1-4) based on the works by van Aalderen-Smeets, Molen [87], where $X$ represents metacognitive knowledge and $Y$ represents mathematical intelligence,

$$
\begin{aligned}
& Q_{1}: X>13 \wedge Y<5 \\
& Q_{2}: X>13 \wedge Y \geq 5
\end{aligned}
$$




$$
\begin{aligned}
& Q_{3}: X \leq 13 \wedge Y \geq 5 \\
& Q_{4}: X \leq 13 \wedge Y<5
\end{aligned}
$$

Four quadrants refer to the four categories of respondents: $\left(Q_{1}\right)$ high metacognitive knowledge, low mathematical intelligence; $\left(Q_{2}\right)$ high metacognitive knowledge, high mathematical intelligence; $\left(Q_{3}\right)$ low metacognitive knowledge, high mathematical intelligence; and $\left(Q_{4}\right)$ low metacognitive knowledge, low mathematical intelligence. Table 2 gives such data as respondents' gender and mean, median, and modus values of the school marks of respondents ( 1 means the best; 5 means the worst) in the four science subjects-biology, physics, geography, and mathematics. Hence, these results are emphasized by the fact that the single quadrants significantly differ both in the field of metacognitive knowledge $(H(3, N=263)=183.3192 ; p<0.001)$ and mathematical intelligence $(H)=164.8041 ; p<0.001$. Post hoc analysis has proven significant differences between the particular pairs of quadrants (Table 2).

The main objective of this study was to develop and verify a new theoretical basis for a four-category model, reflecting the level of metacognitive knowledge and mathematical intelligence. Within this research, the results have proven that metacognitive knowledge and mathematical intelligence are two separate, non-correlating domains $(r=0.016 ; p=0.788)$. Evidently, both domains have their own significant impacts on learners' performance, as displayed in Table 2. If the given respondent is included into the quadrant $Q_{2}$ (high metacognitive knowledge, high mathematical intelligence), then they can achieve significantly better results in school evaluation compared to learners in $Q_{4}$ (low metacognitive knowledge, low mathematical intelligence).

Afterwards, results of the post hoc analysis of $Q_{1}$ (high metacognitive knowledge, low mathematical intelligence) and $Q_{3}$ (low metacognitive knowledge, high mathematical intelligence) proved a statistically significant difference in favor of $Q_{3}$ respondents (Table 3), which leads us to the conclusion that mathematical intelligence provides for a stronger impact on the learners' success in some selected subjects compared to metacognitive knowledge.

\begin{tabular}{|c|c|c|c|c|c|c|c|c|c|c|c|c|c|c|}
\hline \multirow{3}{*}{ Quadrant } & \multicolumn{2}{|c|}{ Gender } & \multicolumn{12}{|c|}{ School Subject } \\
\hline & \multirow{2}{*}{ Male } & \multirow{2}{*}{ Female } & \multicolumn{3}{|c|}{ Biology } & \multicolumn{3}{|c|}{ Physics } & \multicolumn{3}{|c|}{ Geography } & \multicolumn{3}{|c|}{ Mathematics } \\
\hline & & & $\bar{x}$ & $\tilde{x}$ & $\hat{x}$ & $\bar{x}$ & $\tilde{x}$ & $\hat{x}$ & $\bar{x}$ & $\tilde{x}$ & $\hat{x}$ & $\bar{x}$ & $\tilde{x}$ & $\hat{x}$ \\
\hline$Q_{1}$ & 27 & 27 & 1.90 & 2 & 1 & 2.02 & 2 & 2 & 1.96 & 2 & 1 & 2.47 & 2 & 3 \\
\hline $\mathrm{Q}_{2}$ & 19 & 15 & 1.47 & 1 & 1 & 1.44 & 1 & 1 & 1.41 & 1 & 1 & 1.72 & 2 & 1 \\
\hline$Q_{3}$ & 38 & 30 & 1.69 & 1.5 & 1 & 1.67 & 2 & 2 & 1.67 & 1 & 1 & 1.86 & 2 & 2 \\
\hline \multirow[t]{3}{*}{$Q_{4}$} & 53 & 54 & 2.31 & 2 & 2 & 2.51 & 2 & 2 & 2.29 & 2 & 3 & 2.64 & 3 & 2 \\
\hline & & & $U$ & Z & $p$ & $U$ & Z & $p$ & & Z & $p$ & $U$ & Z & $p$ \\
\hline & & & 721 & 4.53 & $* * *$ & 583 & 5.28 & $* * *$ & 702 & 4.59 & $* * *$ & 762 & 4.40 & $* * *$ \\
\hline
\end{tabular}

Table 2. School marks of respondents achieved in different subjects.

Table 3. Differences between the levels of metacognitive knowledge and mathematical intelligence achieved by respondents in the estimated quadrants.

\begin{tabular}{cccccccccc}
\hline \multicolumn{4}{c}{ Metacognitive Knowledge } & \multicolumn{5}{c}{ Mathematical Intelligence } \\
\hline & $Q_{1}$ & $Q_{2}$ & $Q_{3}$ & $Q_{4}$ & & $Q_{1}$ & $Q_{2}$ & $Q_{3}$ & $Q_{4}$ \\
$\bar{x}$ & 16.90 & 2.75 & 17.12 & 6.56 & & 6.71 & 6.92 & 7.46 & 2.12 \\
$\bar{x}$ & 16.00 & 3.00 & 16.00 & 6.00 & & 7.00 & 7.00 & 8.00 & 2.00 \\
$\hat{x}$ & 14.00 & 4.00 & 14.00 & 5.00 & & 2.00 & 5.00 & 9.00 & 2.00 \\
$\mathrm{SD}$ & 3.01 & 1.74 & 3.08 & 1.48 & & 3.80 & 1.56 & 3.68 & 1.24 \\
$Q_{1}$ & - & 0.964 & $<0.001$ & $<0.001$ & $Q_{1}$ & - & $<0.001$ & $<0.001$ & 0.520 \\
$Q_{2}$ & 0.964 & - & $<0.001$ & $<0.001$ & $Q_{2}$ & $<0.001$ & - & 0.896 & $<0.001$ \\
$Q_{3}$ & $<0.001$ & $<0.001$ & - & 0.884 & $Q_{3}$ & $<0.001$ & 0.896 & - & $<0.001$ \\
$Q_{4}$ & $<0.001$ & $<0.001$ & 0.884 & - & $Q_{4}$ & 0.520 & $<0.001$ & $<0.001$ & - \\
\hline \multicolumn{3}{c}{$\bar{x}=$ mean; $\tilde{x}=$ median; $\hat{x}=$ mode; $\mathrm{SD}=$ standard deviation. }
\end{tabular}


If the premise of a "stable" construct of intelligence is accepted, then Rozencwajg [20] summarizes "teaching metacognitive strategies to poor students could therefore be one way of improving their academic achievement level" (p. 289). Definitely, our results support this conclusion fully.

\section{Discussion}

The study aimed to investigate the hypothesized relation between the level of metacognitive knowledge and actual understanding of mathematical intelligence. Furthermore, an influence of both constructs to academic achievement of pupils was confirmed there. The results show that even though both investigated characteristics, metacognitive knowledge and mathematical intelligence have strong impacts on academic performance of pupils, it is the mathematical intelligence that influences their performance levels more. Furthermore, similar influences are observable not only in mathematics, but also in some other subjects as STEM (science, technology, engineering, and mathematics).

Even at the beginning of this century, numerous research findings emphasized the ways how children can gain mathematical knowledge and how these relate to various metacognition aspects $[8,58,62,66,88,89]$ in practice. Interestingly, most of the results are in accordance with our finding that just mathematical intelligence and metacognitive knowledge are the two independent characteristics. This is in contrast with the fact that the learner's choice and ability to generalize some strategy are influenced by the metacognitive and associative processes [90]. As Kuhn [37] states, consequential associative relations arise implicitly-if the strategy results in success, then the associative connection is strengthened profoundly. Factually, metacognitive processes comprising a part of self-regulation training can emphasize an active reflection of strategies applied before, during, and after solving the task. The acquired behavior without metacognitive processes appears soon when the given individual is not exposed to this context. Without some well-timed educational interventions and activation of metacognitive awareness, the active approach to learning while concurrently using objective-oriented strategies would take several years before it was developed and enhanced further on. An advantage of such approach is that the learners, even though led to the metacognitive development only by a sole teacher (though teaching them the only one subject), apply the strategic processes in other subjects [91] as well. Our results support this claim, as the extent of metacognitive knowledge was shown as actually influencing the academic performance level in the four investigated subjects.

However on the other hand, several recent pedagogical experiments proved the metacognitive development through the intentional intervention, i.e., meticulous application of problem-based learning approaches [92]. This may indicate that the mathematical problem solving is a very complex process involving several (independent and interdependent) characteristics of the solver [22].

Obviously, there is a general agreement that metacognitive knowledge in individuals is developed with their age and gained experience as well [93]. These assumptions were confirmed by empirical studies in the context of declarative, relational, and contextual knowledge [94], but the relation does not have to be apparent or obvious there at all. On the other hand, however, Carr states that the declarative knowledge in individuals can be considered as a developmental condition for procedural knowledge, particularly, when applying newly acquired knowledge contrasting to some previously adopted strategies [46]. From the viewpoint of approximate schema of metacognition development, the metacognitive knowledge in individuals is developed first (approximately in the age of 6) and only then, the metacognitive planning is developed later on, in the age of 10 to 14 years, when there is a significant increase in planning abilities as such [95]. The conceptual basis for developing metacognitive knowledge lies in the results of mostly relational studies. Thus, the causal interpretation of the results is not suitable and there it is not possible to identify whether the factors do support or hinder the development of metacognitive knowledge of pupils [96].

Factually, current frequent failures of younger pupils in the field of metacognition may be due to frequent insufficient cognitive sources of attention, limiting these pupils in favor of older pupils or possibly because of their level of cognitive development as such. In order to develop some extent of metacognitive knowledge in pupils, it is necessary to individualize learning tasks so that their difficulty 
is in the subjective levels of demands. Clearly, the reason is simple, as every pupil needs not only to experience success, but also some reasonable application of metacognitive approaches can bring benefits, and provide that teaching tasks are located in a subjectively middle range of demands [97]. In accordance to the context of pedagogical practice, handling the students' failures and errors is also very important [98-100]. Metacognitive aspects in the teaching process are observable during working with pupils' error that can prevent the mathematics anxiety [101]. As a part of this process, the pupil is led to look for an error, to describe it precisely and to interpret the possible causes of it and to correct or eliminate it in the end. We agree with the words of Paris and Winograd, that "metacognition is not seen as the final goal of any learning and teaching..." but, in the contrary, that it is perceived as an opportunity to, "how to pass on knowledge and certainty to pupils that allows them to manage their own apprentices" (p. 22). In the field of metacognitive knowledge the reflection generally should consider the evaluation of contextual effectiveness of the strategies used [102]. The level of demandingness of reflective activities to the teacher may become acceptable because it is not necessary such a teacher has to provide a feedback every time for every cost, however, they can act as the peer in case of group-work or pair-work. Another possibility is that pupils can get the feedback by themselves and find their own precious solution, assuming sufficient previous knowledge. The development of a pupils' metacognitive potential is also possible through encouraging the pupil, what is linked to a number of other factors, such as the classroom culture, the use of different teaching methods and forms, or other factors regulating communication not only in relation to teacher-pupils, but also between pupils themselves. Other recommendations related to the reading with understanding were aptly described by Říčan and Chytrý [103] (p. 239): “To apply such teaching methods that construct a situational text representation and propositional text representation involving not only major ideas but also prior knowledge ... For this type of representation to be constituted, it is necessary to ask: 'How does this information relate to what I already know? What is the main idea of the text? Is there any information in the text that contradicts itself? What information from the text is interesting to me? And for what reasons? What information is completely new to me? What parts of the text do I not understand?'. Since the process of understanding is strongly individual and its quality is largely determined by the level of metacognitive monitoring, a question arises there whether the benefit of this ability arises only if the individual is allowed to manage their learning by themselves." Based on this, it seems that pupils require more time and support to manage simultaneously both, their learning and their use of metacognition.

Mathematical intelligence is defined here as a specific sensitivity to carefully chosen phenomena. Pupils' skills based on their assumptions to perceive these phenomena correctly can be developed to some extent. Mathematical intelligence can be developed in the field of geometric imagination [104-106], functional thinking $[107,108]$ and perception of infinity $[53,109,110]$. The phenomenon of causality is naturally reflected in the process of solving different mathematical problems, without the perception of this phenomenon, and then and following, judgment cannot be made. Development of pupil's skills to perceive the issue of existence and uniqueness of solution of a mathematical problem can be supported by including appropriate experience in mathematics education. These should be problems from some different fields of mathematics, but they should have the one common feature-either they do not have a solution or they have more than one solution. The fact that mathematical problems can have more than one solution is usually not stressed enough and experiencing this kind of problems can be very valuable [111].

\section{Conclusions}

Mathematics operates as a basis of development for many other subjects. The development of learners' skills in the STEM field is a good pre-condition for development of more general skills that are necessary, useful and utilized in other educational fields as well. Hence, our results aim at supporting the teacher's diagnostic competence and interpretation of diagnostic results that may lead the teacher to optimize the process of instructions. The learner's success (performance) in solving 
tasks in mathematics is impacted by both investigated factors vesting in mathematical intelligence and metacognitive knowledge. The direct link between metacognitive knowledge and mathematical intelligence was examined. The results show that metacognitive knowledge and mathematical intelligence are two separate domains not correlating mutually at all; therefore, a two-dimensional model was designed. Moreover, the learner's classification according to the four categories $\left(Q_{1}-Q_{4}\right)$ is reflected in their school success in the all selected subjects (biology, physics, geography, mathematics). However, the ability to solve tasks is not given by these two domains only but by other factors as well (in particular and mainly: motivation, self-efficacy, reading comprehension, creativity, working memory, the existing knowledge etc.). Further research activities, thus, can focus on both mathematics (correlation studies of other aspects and mathematics) and other domains (correlation of metacognitive knowledge, level in reading, motivation, and self-efficacy).

It seems more than reasonable to include some specific activities leading to developing the metacognitive knowledge level in the day-to-day teaching, particularly, in mathematics education as such. The authors are not aware of any interventional study in the context of the Czech Republic or Slovakia assessing the impacts of metacognitive intervention. Further research, particularly, fully evaluating intervention projects in metacognitive intervention, may benefit from the presented evidence about the independence of the two investigated concepts, mathematical intelligence and metacognitive knowledge.

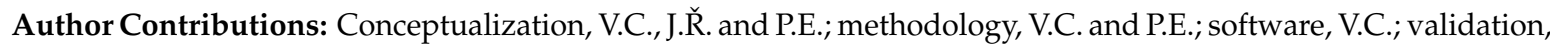
J.M.; formal analysis, V.C. and J.M.; investigation, V.C.; data curation, V.C. and J.M.; writing-original draft

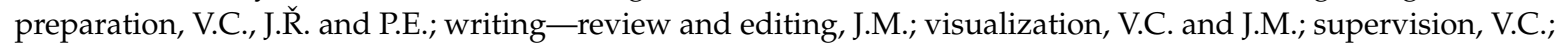
project administration, V.C.; funding acquisition, V.C., J. ̌̌., P.E. and J.M. All authors have read and agreed to the published version of the manuscript.

Funding: This research was supported by two projects conducted at University of Jan Evangelista Purkyne, Ústí nad Labem 40096, Czech Republic: IGA PF UJEP and UJEP-SGS-2020-43-007-3, by the Czech Republic Technology Agency, project TL02000200-V2. This work was also supported by the Slovak Research and Development Agency under the contract No. APVV-15-0368 and by the Scientific Grant Agency of the Ministry of Education, Science, Research and Sport of the Slovak Republic and the Slovak Academy of Sciences under the contract No. VEGA 1/0815/18.

Conflicts of Interest: The authors declare no conflict of interest. The funders had no role in the design of the study; in the collection, analyses, or interpretation of data; in the writing of the manuscript, or in the decision to publish the results.

\section{References}

1. Morosanova, V.I.; Fomina, T.G.; Kovas, Y.; Bogdanova, O.Y. Cognitive and regulatory characteristics and mathematical performance in high school students. Personal. Individ. Differ. 2016, 90, 177-186. [CrossRef]

2. Eisenmann, P.; Novotná, J.; Přibyl, J.; Břehovský, J. The development of a culture of problem solving with secondary students through heuristic strategies. Math. Ed. Res. J. 2015, 27, 535-562. [CrossRef]

3. Sriraman, B. Mathematical intelligence. Encycl. Gift. Creat. Talent. 2009, 2, 544-547.

4. Özsoy, G. An investigation of the relationship between metacognition and mathematics achievement. Asia Pac. Educ. Rev. 2011, 12, 227-235. [CrossRef]

5. Vo, V.A.; Li, R.; Kornell, N.; Pouget, A.; Cantlon, J.F. Young Children Bet on Their Numerical Skills:Metacognition in the Numerical Domain. Psychol. Sci. 2014, 25, 1712-1721. [CrossRef]

6. Cornoldi, C.; Carretti, B.; Drusi, S.; Tencati, C. Improving problem solving in primary school students: The effect of a training programme focusing on metacognition and working memory. Br. J. Educ. Psychol. 2015, 85, 424-439. [CrossRef]

7. Van der Stel, M.; Veenman, M.V.J.; Deelen, K.; Haenen, J. The increasing role of metacognitive skills in math: A cross-sectional study from a developmental perspective. ZDM 2010, 42, 219-229. [CrossRef]

8. Rottier, K.L. Metacognition and Mathematics During the 5 to 7 Year Shift; Illinois Institute of Technology: Chicago, IL, USA, 2003.

9. Lucangeli, D.; Coi, G.; Bosco, P. Metacognitive awareness in good and poor math problem solvers. Learn. Disabil. Res. Pract. 1997, 12, 209-212. 
10. Carr, M.; Jessup, D.L. Cognitive and metacognitive predictors of mathematics strategy use. Learn. Individ. Differ. 1995, 7, 235-247. [CrossRef]

11. Larkin, S. Socially mediated metacognition and learning to write. Think. Ski. Creat. 2009, 4, 149-159. [CrossRef]

12. Schneider, W.; Artelt, C. Metacognition and mathematics education. ZDM 2010, 42, 149-161. [CrossRef]

13. Vomáčková, H.; Říčan, J.; Šlégl, J.; Chytrý, V.; Ladislav, Z. Výzkumný pohled na inkluzi a jeji determinanty; Univerzita JE Purkyně: Ústí nad Labem, Czech Republic, 2015.

14. Poon, C.L.; Lam, K.W.; Chan, M.; Chng, M.; Kwek, D.; Tan, S. Preparing Students for the Twenty-First Century: A Snapshot of Singapore's Approach. In Educating for the 21st Century: Perspectives, Policies and Practices from Around the World; Choo, S., Sawch, D., Villanueva, A., Vinz, R., Eds.; Springer: Singapore, 2017; pp. 225-241.

15. Kohen, Z.; Kramarski, B. Promoting Mathematics Teachers' Pedagogical Metacognition: A TheoreticalPractical Model and Case Study. In Cognition, Metacognition, and Culture in STEM Education: Learning, Teaching and Assessment; Dori, Y.J., Mevarech, Z.R., Baker, D.R., Eds.; Springer International Publishing: Cham, Switzerland, 2018; pp. 279-305.

16. Duchovičová, J.; Tomšík, R. Managerial Competencies of a Teacher in the Context of Learners' Critical Thinking Development: Exploratory Factor Analysis of a Research Tool and the Results of the Research. TEM J. Technol. Educ. Manag. Inform. 2018, 7, 335-347.

17. Perry, J.; Lundie, D.; Golder, G. Metacognition in schools: What does the literature suggest about the effectiveness of teaching metacognition in schools? Educ. Rev. 2019, 71, 483-500. [CrossRef]

18. Swanson, H.L. Influence of metacognitive knowledge and aptitude on problem solving. J. Educ. Psychol. 1990, 82, 306-314. [CrossRef]

19. Howard, B.; McGee, S.; Shia, R.; Hong, N. Metacognitive Self-Regulation and Problem-Solving: Expanding the Theory Base through Factor Analysis; American Educational Research Assotiation: New Oreleans, LA, USA, 2000.

20. Rozencwajg, P. Metacognitive factors in scientific problem-solving strategies. Eur. J. Psychol. Educ. 2003, 18, 281-294. [CrossRef]

21. Gonzalez-Castro, P.; Cueli, M.; Cabeza, L.; Alvarez-Garcia, D.; Rodriguez, C. Improving basic math skills through integrated dynamic representation strategies. Psicothema 2014, 26, 378-384.

22. Schoenfeld, A.H. Learning to think mathematically: Problem solving, metacognition, and sense making in mathematics. In Handbook of Research on Mathematics Teaching and Learning; Grouws, D., Ed.; Macmillan: New York, NY, USA, 1992.

23. Hensberry, K.K.R.; Jacobbe, T. The effects of Polya's heuristic and diary writing on children's problem solving. Math. Ed. Res. J. 2012, 24, 59-85. [CrossRef]

24. Jeřábek, J.; Lisnerová, R.; Smejkalová, A.; Tupý, J. Rámcový vzdělávací program pro základní vzdělávání:(verze platná od 1. 9. 2013) úplné znění upraveného RVP ZV. Available online: www.nuv.cz (accessed on 23 April 2020).

25. NCTM. Principles and Standards for School Mathematics; The National Council of Teachers of Mathematics, Inc.: Reston, VA, USA, 2000.

26. Grofčíková, S.; Duchovičová, J.; Fenyvesiová, L. Development of future teachers' critical thinking through pedagogical disciplines Slavon. Pedagog. Stud. J. Sci. Educ. J. 2018, 7, 101-109.

27. Kilpatrick, J.; Swafford, J.; Findell, B. The strands of mathematical proficiency. In Adding It up: Helping Children Learn Mathematics; Council, N.R., Ed.; The National Academies Press: Washington, DC, USA, 2001; pp. 115-154.

28. Veenman, M.V.J.; Van Hout-Wolters, B.H.A.M.; Afflerbach, P. Metacognition and learning: Conceptual and methodological considerations. Metacogn. Learn. 2006, 1, 3-14. [CrossRef]

29. Tobias, S.; Everson, H.T. Knowing What You Know and What You Don't: Further Research on Metacognitive Knowledge Monitoring; Research Report No. 2002-3; College Entrance Examination Board: New York, NY, USA, 2002.

30. Kramarski, B.; Mevarech, Z.R. Enhancing Mathematical Reasoning in the Classroom: The Effects of Cooperative Learning and Metacognitive Training. Am. Educ. Res. J. 2003, 40, 281-310. [CrossRef]

31. Desoete, A.; De Craene, B. Metacognition and mathematics education: An overview. ZDM 2019, 51, 565-575. [CrossRef] 
32. Garofalo, J.; Lester, F.K. Metacognition, Cognitive Monitoring, and Mathematical Performance. J. Res. Math. Educ. 1985, 16, 163-176. [CrossRef]

33. Schoenfeld, A.H. Mathematical Problem Solving; Academic Press: Cambridge, MA, USA, 1985.

34. Schoenfeld, A.H. What's all the fuss about metacognition. Cogn. Sci. Math. Educ. 1987, 189, 215.

35. Carr, M. The importance of metacognition for conceptual change and strategy use in mathematics. In Metacognition Strategy Use Instruction; Guilford Press: New York, NY, USA, 2010; pp. 176-197.

36. Azevedo, R. Theoretical, conceptual, methodological, and instructional issues in research on metacognition and self-regulated learning: A discussion. Metacogn. Learn. 2009, 4, 87-95. [CrossRef]

37. Kuhn, D. A Developmental Model of Critical Thinking. Educ. Res. 1999, 28, 16-46. [CrossRef]

38. Jacobs, J.E.; Paris, S.G. Children's Metacognition About Reading: Issues in Definition, Measurement, and Instruction. Educ. Psychol. 1987, 22, 255-278.

39. McCormick, C.B. Metacognition and learning. In Handbook of Psychology: Volume 7-Eduacational Psychology; Weiner, I.B., Reynolds, W.M., Miller, G.E., Eds.; John Wiley \& Sons, Inc.: Hoboken, NJ, USA, 2003; pp. 79-102.

40. Borkowski, J.G.; Milstead, M.; Hale, C. Components of children's metamemory: Implications for strategy generalization. In Memory Development: Universal Changes and Individual Differences; Lawrence Erlbaum Associates: Hillsdale, NJ, USA, 1988; pp. 73-100.

41. Sperling, R.A.; Howard, B.C.; Miller, L.A.; Murphy, C. Measures of Children's Knowledge and Regulation of Cognition. Contemp. Educ. Psychol. 2002, 27, 51-79. [CrossRef]

42. Wirth, J.; Leutner, D. Self-regulated learning as a competence: Implications of theoretical models for assessment methods. Z. Für Psychol. J. Psychol. 2008, 216, 102-110. [CrossRef]

43. Schlagmüller, M.; Schneider, W. Würzburger Lesestrategie-Wissenstest für die Klassen 7-12. In Ein Verfahren zur Erfassung Metakognitiver Kompetenzen bei der Verarbeitung von Texten; Hogrefe: Göttingen, Germany, 2007.

44. Artelt, C.; Beinicke, A.; Schlagmüller, M.; Schneider, W. Diagnose von Strategiewissen beim Textverstehen. Z. Für Entwickl. und Pädagogische Psychol. 2009, 41, 96-103. [CrossRef]

45. Thillmann, H.; Gößling, J.; Marschner, J.; Wirth, J.; Leutner, D. Metacognitive Knowledge About and Metacognitive Regulation of Strategy Use in Self-Regulated Scientific Discovery Learning: New Methods of Assessment in Computer-Based Learning Environments. In International Handbook of Metacognition and Learning Technologies; Azevedo, R., Aleven, V., Eds.; Springer: New York, NY, USA, 2013; pp. 575-588.

46. Carr, M.; Alexander, J.; Folds-Bennett, T. Metacognition and mathematics strategy use. Appl. Cogn. Psychol. 1994, 8, 583-595. [CrossRef]

47. Teong, S.K. The effect of metacognitive training on mathematical word-problem solving. J. Comput. Assist. Learn. 2003, 19, 46-55. [CrossRef]

48. Lester, F.K.; Garofalo, J.; Kroll, D.L. Self-Confidence, Interest, Beliefs, and Metacognition: Key Influences on Problem-Solving Behavior. In Affect and Mathematical Problem Solving: A New Perspective; McLeod, D.B., Adams, V.M., Eds.; Springer: New York, NY, USA, 1989; pp. 75-88.

49. Perrenet, J.C.; Wolters, M.A. The art of checking: A case study of students' erroneous checking behavior in introductory algebra. J. Math. Behav. 1994, 13, 335-358. [CrossRef]

50. Wenke, D.; Frensch, P.A.; Funke, J. Complex problem solving and intelligence: Empirical relation and causal direction. In Cognition and Intelligence: Identifying the Mechanisms of the Mind; Sternberg, R.J., Pretz, J.E., Eds.; Cambridge University Press: Cambridge, UK, 2005; pp. 160-187.

51. Eysenck, H.J. The structure and measurement of intelligence. Naturwissenschaften 1981, 68, 491-497. [CrossRef] [PubMed]

52. Cihlář, J.; Eisenmann, P.; Hejnová, E.; Přibyl, J. Pupils' abilities to solve problems in mathematics and physics and their school performance. In Proceedings of the 15th International Conference Efficiency and Responsibility in Education 2018, Prague, Czech Republic, 7-8 June 2018; pp. 29-35.

53. Shearer, C.B. A resting state functional connectivity analysis of human intelligence: Broad theoretical and practical implications for multiple intelligences theory. Psychol. Neurosci. 2020. [CrossRef]

54. Juter, K.; Sriraman, B. Does High Achieving in Mathematics = Gifted and/or Creative in Mathematics? In The Elements of Creativity and Giftedness in Mathematics; Sriraman, B., Lee, K.H., Eds.; SensePublishers: Rotterdam, The Netherlands, 2011; pp. 45-65.

55. Wahl, H.M. Math for Humans: Teaching Math through 8 Intelligences; LivnLern Press: Langley, WA, USA, 1999.

56. Gardner, H. The Theory of Multiple Intelligences; Heinemann: Portsmouth, NH, USA, 1983. 
57. Gardener, H.; Gardner, H. Intelligence Reframed: Multiple Intelligences for the 21st Century; Basic Books: New York, NY, USA, 1999.

58. Veenman, M.V.J.; Spaans, M.A. Relation between intellectual and metacognitive skills: Age and task differences. Learn. Individ. Differ. 2005, 15, 159-176. [CrossRef]

59. Skemp, R.R. Intelligence, Learning, and Action: A Foundation for Theory and Practice in Education; Wiley: Hoboken, NJ, USA, 1979.

60. Piaget, J. The Grasp of Consciousness: Action and Concept in the Young Child. (Trans by S. Wedgwood); Harvard University Press: Cambridge, MA, USA, 1976.

61. Schraw, G. Promoting General Metacognitive Awareness. Instr. Sci. 1998, 26, 113-125. [CrossRef]

62. Veenman, M.V.J.; Wilhelm, P.; Beishuizen, J.J. The relation between intellectual and metacognitive skills from a developmental perspective. Learn. Instr. 2004, 14, 89-109. [CrossRef]

63. Piaget, J.; Cook, M. The Origins of Intelligence in Children; International Universities Press: New York, NY, USA, 1952; Volume 8.

64. Inhelder, B.; Piaget, J. The Growth of Logical Thinking from Childhood to Adolescence: An Essay on the Construction of Formal Operational Structures (Developmental Psychology); Basic Books: New York, NY, USA, 1958.

65. Kuzle, A. Assessing metacognition of grade 2 and grade 4 students using an adaptation of multi-method interview approach during mathematics problem-solving. Math. Ed. Res. J. 2018, 30, 185-207. [CrossRef]

66. Veenman, M.V.J. The role of intelectual and metacognitive skills in math problem solving. In Metacognition in Mathematics Education; Desoete, A., Veenman, M., Eds.; Nova Science: Haupauge, NY, USA, 2006; pp. 35-50.

67. Berk, L. Child Development, 6th ed.; Allyra and Bacon: Boston, MA, USA, 2003.

68. Cross, D.R.; Paris, S.G. Developmental and intructional analysis of children's metacognition and reading comprehention. J. Educ. Psychol. 1988, 80, 131-142.

69. Whitebread, D.; Bingham, S.; Grau, V.; Pino Pasternak, D.; Sangster, C. Development of Metacognition and Self-Regulated Learning in Young Children: Role of Collaborative and Peer-Assisted Learning. J. Cogn. Educ. Psych. 2007, 6, 433-455. [CrossRef]

70. Sternberg, R.J.; Rifkin, B. The development of analogical reasoning processes. J. Exp. Child Psychol. 1979, 27, 195-232. [CrossRef]

71. Hejný, M. Exploring the cognitive dimension of teaching mathematics through scheme-oriented approach to education. Orb. Sch. 2012, 6, 41-55. [CrossRef]

72. Götz, L.; Lingel, K.; Artelt, C.; Schneider, W. Mathematisches Strategie wissen für 5. und 6. Klassen (MAESTRA 5-6); Hogrefe: Göttingen, Germany, 2013.

73. Lingel, K.; Götz, L.; Artelt, C.; Schneider, W. Mathematisches Strategiewissen für 5. und 6. Klassen: MAESTRA 5-6+. Hogrefe-Schultests. [Mathematical Strategy Knowledge for 5th and 6th Classes: MAESTRA 5-6 +. Hogrefe-school tests].; Hogrefe: Göttingen, Germany, 2014.

74. Chytrý, V.; Pešout, O.; Říčan, J. Preference Metakognitivních Strategií na Pozadí Úkolových Situacív Matematice u Žáků Druhého Stupně ZŠ; UJEP: Ústí nad Labem, Czech Republic, 2014.

75. Polya, G. How to Solve it: A New Aspect of Mathematical Methods; Doubleday: New York, NY, USA, 1957.

76. Polit, D.F.; Beck, C.T. Nursing Research: Principles and Methods; Lippincott Williams \& Wilkins: Philadelphia, PA, USA, 2004.

77. Vandenberg, S.G.; Kuse, A.R. Mental Rotations, a Group Test of Three-Dimensional Spatial Visualization. Percept. Mot. Ski. 1978, 47, 599-604. [CrossRef] [PubMed]

78. Torrance, E.P. Norms Technical Manual: Torrance Tests of Creative Thinking; Ginn and Company: Lexington, MA, USA, 1974.

79. Eysenck, H.J. Intelligence: A New Look; Transaction Publishers: Piscataway, NJ, USA, 1998.

80. Cronbach, L.J.; Meehl, P.E. Construct validity in psychological tests. Psychol. Bull. 1955, 52, 281. [CrossRef] [PubMed]

81. McGartland Rubio, D. Alpha reliability. In Encyclopedia of Social Measurement (59-63); Elsevier: Amsterdam, The Netherlands, 2005.

82. Shoukri, M.M.; Cihon, C. Statistical Methods for Health Sciences; CRC Press: Boca Raton, FL, USA, 1998.

83. Shapiro, S.S.; Wilk, M.B. An Analysis of Variance Test for Normality (Complete Samples). Biometrika 1965, 52, 591-611. [CrossRef]

84. Kruskal, W.H.; Wallis, W.A. Use of Ranks in One-Criterion Variance Analysis. J. Am. Stat. Assoc. 1952, 47, 583-621. [CrossRef] 
85. Dunn, O.J. Multiple Comparisons Using Rank Sums. Technometrics 1964, 6, 241-252. [CrossRef]

86. Chráska, M. Metody pedagogického výzkumu [Methods of Educational Research]; Grada Publishing: Prague, Czech Republic, 2007.

87. van Aalderen-Smeets, S.; van der Molen, J.W. Measuring Primary Teachers' Attitudes Toward Teaching Science: Development of the Dimensions of Attitude Toward Science (DAS) Instrument. Int. J. Sci. Educ. 2013, 35, 577-600. [CrossRef]

88. Downing, K.; Kwong, T.; Chan, S.-W.; Lam, T.-F.; Downing, W.-K. Problem-based learning and the development of metacognition. High. Educ. 2009, 57, 609-621. [CrossRef]

89. Brown, A.L.; Palincsar, A.S. Inducing Strategic Learning from Texts by Means of Informed, Self-Control Training; Center for the Study of Reading Technical Report No. 262; University of Illinois at Urbana-Champaign: Champaign, IL, USA, 1982.

90. Crowley, K.; Shrager, J.; Siegler, R.S. Strategy Discovery as a Competitive Negotiation between Metacognitive and Associative Mechanisms. Dev. Rev. 1997, 17, 462-489. [CrossRef]

91. Kuhn, D. Does Memory Development Belong on an Endangered Topic List? Child Dev. 2000, 71, 21-25. [CrossRef] [PubMed]

92. Veenman, M.V.J.; Verheij, J. Technical students' metacognitive skills: Relating general vs. specific metacognitive skills to study success. Learn. Individ. Differ. 2003, 13, 259-272. [CrossRef]

93. Veenman, M.V.J.; Kok, R.; Blöte, A.W. The relation between intellectual and metacognitive skills in early adolescence. Instr. Sci. 2005, 33, 193-211. [CrossRef]

94. Lara Nieto-Márquez, N.; Baldominos, A.; Pérez-Nieto, M.Á. Digital Teaching Materials and Their Relationship with the Metacognitive Skills of Students in Primary Education. Educ. Sci. 2020, 10, 113. [CrossRef]

95. Schneider, W. The Development of Metacognitive Knowledge in Children and Adolescents: Major Trends and Implications for Education. Mind Brain Educ. 2008, 2, 114-121. [CrossRef]

96. Neuenhaus, N. Metakognition und Leistung. Eine Längschnittuntersuchung in den Bereichen Lesen und Englisch bei Schülerinnen und Schülern der fünften und sechsten Jahrgangsstufe. Ph.D. Thesis, Bamberg University, Bamberg, Germany, 2011.

97. Lai, E.R. Metacognition: A literature review. Always Learn. Pearson Res. Rep. 2011, 24. Available online: http://images.pearsonassessments.com/images/tmrs/metacognition_literature_review_final.pdf (accessed on 15 March 2020).

98. Boaler, J. Mathematical mindsets: Unleashing students' potential through creative math. In Inspiring Messages and Innovative Teaching; John Wiley \& Sons: Hoboken, NJ, USA, 2015.

99. Petty, G. Moderní vyučování [Modern teaching]; Portál: Prague, Czech Republic, 1996.

100. Helus, Z.; Pavelková, I. Vedení žáků ke vzdělávací autoregulaci a humanizaci školy. Pedagogika 1992, 42, 197-208.

101. Švecová, V. Mathematics Anxiety and Other Psycho Didactic Aspects in University Students. J. Educ. Soc. Policy 2018, 5, 246-250. [CrossRef]

102. Paris, S.G.; Winograd, P. How metacognition can promote academic learning and instruction. In Dimensions of Thinking and Cognitive Instruction; Lawrence Erlbaum Associates, Inc.: Hillsdale, NJ, USA, 1990; pp. $15-51$.

103. Ǩ́čcan, J.; Chytrý, V. Metakognice a Metakognitioní Strategie Jako Teoretické a Výzkumné Konstrukty a Jejich Uplatnění v Moderní Pedagogické Praxi; UJEP: Ústí nad Labem, Czech Republic, 2016.

104. Páleníková, K.; Bugárová, M. Aktivity na rozvoj geometrických predstáv žiakov mladšieho školského veku [Activities for the development of geometric conceptions of pupils in primary education]. Online J. Prim. Presch. Educ. 2018, 2, 23-32.

105. Vallo, D.; Rumanova, L.; Duris, V. Spatial Imagination Development through Planar Section of Cube Buildings in Educational Process. Procedia Soc. Behav. Sci. 2015, 191, 2146-2151. [CrossRef]

106. van Hiele, P.M. Developing Geometric Thinking through Activities That Begin with Play. Teach. Child. Math. 1999, 5, 310-316.

107. Wilkie, K.J.; Clarke, D.M. Developing students' functional thinking in algebra through different visualisations of a growing pattern's structure. Math. Ed. Res. J. 2016, 28, 223-243. [CrossRef]

108. Eisenmann, P. A contribution to the development of functional thinking of pupils and students. Teach. Math. 2009, XII, 73-81.

109. Katz, K.U.; Katz, M.G. Zooming in on infinitesimal 1-.9.. in a post-triumvirate era. Educ. Stud. Math. 2010, 74, 259-273. [CrossRef] 
110. Cihlář, J.; Eisenmann, P.; Krátká, M. Omega Position-A specific phase of perceiving the notion of infinity. Sci. Educ. 2015, 6, 51-73.

111. Čeretková, S.; Bulková, K.; Jenisová, Z.; Kramáreková, H.; Lovászová, G.; Nemčíková, M.; Rampašeková, Z.; Sandanusová, A.; Schlarmannová, J.; Valovičová, L'. Stratégie Tvorivého a Kritického Myslenia v Príprave Učitel'ov Prírodovedných Predmetov, Matematiky a Informatiky= Creative and Critical Thinking Strategies in Training Future Teachers of Natural Sciences, Mathematics, and Computer Science; Univerzita Konštantína Filozofa v Nitre: Nitra, Slovakia, 2017. article distributed under the terms and conditions of the Creative Commons Attribution (CC BY) license (http://creativecommons.org/licenses/by/4.0/). 